\title{
Altered Distribution of Interstitial Cells of Cajal in Normoganglionic and Transitional Zone of Hirschsprung Disease and Their Clinical Significance
}

\author{
Radmila Jankovic $^{1,2}$, Sanja Sindjic-Antunovic ${ }^{1,3}$, Marija Lukac ${ }^{1,3}$, Dragana Vujovic ${ }^{1,3}$, Jovan Jevtic ${ }^{1,2}$, \\ Milica Skender-Gazibara ${ }^{1,2}$ \\ ${ }^{1}$ Faculty of Medicine, University of Belgrade, Belgrade, Serbia, ${ }^{2}$ Institute of Pathology, Belgrade, Serbia, ${ }^{3}$ University Children's \\ Hospital, Belgrade, Serbia
}

Correspondence: radmila.jankovic011@gmail.com; Tel.: + 381113643 339; Fax.: + 381113643346

Received: November 30, 2019; Accepted: January 30, 2020

\begin{abstract}
Objective - The aim of this study was to evaluate interstitial cells of Cajal (ICC) in Hirschsprung disease (HD), especially in children who had postsurgical problems. Material and Methods - The study included tissue samples of normoganglionic (NZ) and transitional zone (TZ) of 33 HD pediatric patients. Samples of bowel from 10 autopsy controls who did not have dysmotility were also analyzed. Hematoxylin-eosin (H\&E) and immunohistochemical (MAP-2 and c-Kit (CD117)) staining were performed. Myenteric ganglia were analyzed at 5 microscopic fields H\&E and MAP-2 stained sections (magnification 400x). The diameters of the submucosal nerves were measured at 3 microscopic H\&E fields (magnification 400x). The ICC were analyzed on c-Kit immunostained slides at 3 microscopic fields per each bowel layer (magnification 200x): deep submucosa, circular and longitudinal muscular layer and zone of myenteric plexus. Results - The myenteric ganglion cell count was significantly lower in TZ of all children with HD, while there were no significant differences in NZ between the study group and age-matched controls. The ICC network was affected in all cases of HD. The total ICC count was significantly lower in NZ than in control $(\mathrm{P}<0.001)$. A critically lower ICC count ( $<50 \%$ of minimal ICC count in the control group) in the NZ was found in patients with postoperative problems (constipation and enterocolitis). Conclusion - Decreased count of the ICC in the NZ could be the cause of intestinal motility difficulties in the postoperative period in children with HD.
\end{abstract}

Key Words: Hirschsprung Disease • Interstitial Cells of Cajal • Enteric Nervous System.

\section{Introduction}

Hirschsprung disease (HD) is a congenital aganglionosis of the rectum and the adjacent bowel, with higher incidence in male infants (1). There are three different zones in the affected HD bowel: aganglionic, transitional (TZ) and normoganglionic zone (NZ). The TZ is a funnel-shaped bowel segment, $1-3 \mathrm{~cm}$ in length, located between the aganglionic segment and the NZ, with gradual appearance of ganglion cells in the enteric nervous plexuses. Myenteric hypoganglionosis is obligatory characteristic of the TZ, as well as the presence of thick nerve fibers $(\geq 40 \mu \mathrm{m})(2,3)$. Presence of the TZ on prox- imal surgical margin could be the reason for the persistence of postoperative pseudoobstruction (2). However, persistent bowel dysfunction is present in some infants with HD despite an adequate surgical resection (4). In the postoperative period, constipation, enterocolitis, soiling frequently occur (5).

Motility of gastrointestinal tract is controlled by the enteric nervous system and interstitial cells of Cajal (ICC). ICC produce electrical impulses which cause slow peristaltic contraction (6). They have mesodermal origin and express tyrosine-kinase receptor, which is recognised by c-Kit antibody (CD117). ICC are interposed between smooth muscle fibres and neurons. Previously reported data 
about ICC in HD remain controversial (7). While some authors describe normal distribution of ICC in $\operatorname{HD}(8,9)$, others describe reduction of the ICC network in the affected HD bowel (10). Also, some authors noticed reduced count of the ICC in NZ and found it associated with postoperative intestinal dysmotility $(11,12)$.

The aim of our study was to evaluate the ICC in transitional (TZ) and normoganglionic zone (NZ) in the HD affected bowel, with special emphasis on cases with postoperative symptoms of bowel dysfunction.

\section{Methods}

\section{Material}

We analyzed samples of colon from 33 children surgically treated at the University Children's Hospital, Belgrade due to HD in the period from 2008 - 2015. All cases were previously diagnosed at the Institute of Pathology, Faculty of Medicine, University of Belgrade. Thirty patients were boys and three were girls, aged between 1 month and 16 years. The vast majority of children $(27 / 33,82 \%)$ underwent transanal endorectal pull-through resection using the de la Torre and Ortega (TEPT) surgical technique. The Swenson's or Duhamell's techniques were applied in six HD cases. A classical rectosigmoid type of $\mathrm{HD}$ was diagnosed in most children (29/33, 88\%). Ultrashort type of HD was diagnosed in 3 children (9\%), while long segment of $\mathrm{HD}$ was diagnosed in only one (3\%) child.

All resected bowels were fixed by immersion in $10 \%$ formalin. Representative sections from each zone were sampled, processed and paraffin embedded. After routine analysis of haematoxylin and eosin (H\&E) stained sections, longitudinal sections from NZ (including proximal surgical margine) and TZ were chosen for further analysis. Aganglionic bowel segment contained only mucosa and submucosa in cases where the TEPT technique was applied. Due to specificity of TEPT technique, aganglionic segment was not evaluated in the present study.

Longitudinal tissue sections of the sigmoid colon from paediatric autopsy cases were used as controls (neonates and infants). None of them had any history of intestinal dysmotility. In 10 autopsies samples were suitable for further immunohistochemical analysis. The control group was comprised of six boys and four girls, aged 5 days to 2 months. The control tissue sections were processed in the same way as the HD specimens (formalin fixed, paraffin embedded, H\&E stained).

\section{Immunobistochemistry}

Selected paraffin tissue blocks were cut into $5 \mu \mathrm{m}$ thick sections. Two sections from each sample were immunostained (MAP-2 and c-Kit). The distance between the MAP-2 immunostained section and $\mathrm{H} \& \mathrm{E}$ routinely stained section was 18 sections (90 $\mu \mathrm{m})$ in order to avoid inclusion of same ganglion cells (13).

MAP-2 antibody (mouse monoclonal antibody, Abcam, ab11267, dilution 1:500) was applied for detection of the ganglion cells. The MAP-2 had cytoplasmatic staining pattern in the ganglion cells. Omission of the primary antibody served as a negative control.

ICC visualisation was performed by the c-Kit primary antibody (polyclonal rabbit anti-human antibody, Dako, clone5) diluted 1:400. The appearance of ICC stained by this method was revealed characteristic elongated cells with processes. Mast cells were also c-Kit positive (7); however, they had different morphology - round shape and granular content (14). The c-Kit immunopositivity in mast cells was internal positive control.

\section{Evaluation of $N Z$ and $T Z$ (Analysis of Myenteric Ganglion Cells and Diameter of Submucosal Nerves)}

We evaluated the count of myenteric ganglion cells because one of the main criteria for differentiation of $\mathrm{TZ}$ and $\mathrm{NZ}$ is the state of myenteric plexus $(2,3)$. Ganglion cells in the myenteric plexus were counted on $5 \mathrm{HPF}$ (magnification $\times 400$ ) on $\mathrm{H} \& \mathrm{E}$ and MAP-2 section per each tissue block. We counted only ganglion cells in myenteric ganglia, with visible nuclei. During microscopic examina- 
tion (Olympus BX41) five consecutive microphotographies (Olympus DP70 camera) per one section were captured, after which the ganglion cells were counted using image processing software ImageJ, an open access software available from http:// imagej.nih.gov/ij/. The total length of the analyzed zone of the myenteric plexus per one specimen was $4.2 \mathrm{~mm}$.

In all sections we measured the diameter of the present submucosal nerves. Three microphotographs with the thickest nerves were captured (magnification $\times 400$ ) on H\&E and saved as tiff files. The measurements of nerve diameter were performed using the ImageJ free software.

\section{Quantitative Evaluation of the Interstitial Cells of Cajal (ICC)}

The ICC were analyzed under the microscope (Olympus BX41) and counted in deep submucosal zone over the circular muscle layer (ICC-SM), in the circular (ICC-CM) and longitudinal (ICC-LM) smooth muscle layer and in the zone of the myenteric nervous plexus (ICC-MP) (15). Only cells with visible nuclei and processes were counted. The ICC counting was done on three microphotographs (Olympus DP70 camera), per each of the above mentioned zones, captured at magnification $\times 200$. The dimensions of microphotographs at magnification $\times 200$ were $0.86 \times 0.65 \mathrm{~mm}$. In all samples the total estimated areas per ICC-SM, ICC-CM and ICC-LM were $1.68 \mathrm{~mm}^{2}$ and the total length of ICC-MP zone per one specimen was $2.58 \mathrm{~mm}$. The ICC counts of less than $50 \%$ of the lowest control count were assumed to be significantly diminished (according to the recommendation of Gastro 2009 International Working Group (16)).

\section{Ethics Statement}

This study was approved the Ethics Committee of the Faculty of Medicine, University of Belgrade (Approval no. 29/VII-2, issued on July 1, 2015) and the Children's University Hospital in Belgrade (Approval no. 26/185, Issued on June 4, 2015).

\section{Statistical Analyses}

All statistical analyses were performed using the Easy R (EZR) software package (Saitama Medical CenterJichi Medical University, Saitama, Japan) (17) along with a graphical user interface for the R software package (version 3.1.1; The R Foundation for Statistical Computing). For testing of differences in count of ganglion cells and ICC and nerve diameter between the TZ and the NZ, Wilcoxon's signed rank test was used, while Mann-Whitney $\mathrm{U}$ test was used to test the differences in ICC count between the study group and the control group. Spearman's rank correlation test was used for the evaluation of the degree of correlation between the examined parameters. A P-value of $<0.05$ indicated statistical significance.

\section{Results}

\section{Clinical Data}

The vast majority of children $(31 / 33,94 \%)$ had some symptoms due to intestinal dysmotility beginning in the neonatal period, but only half $(16 / 33$; $48 \%$ ) was diagnosed as HD. Ten patients (30\%) were diagnosed as HD in infancy. The HD diagnosis was ascertained after first year of life in 7 (21\%) children. Most children with HD did not have postoperative difficulties. Three (9\%) children suffered from postoperative constipation. One child (3\%) developed postsurgical enterocolitis 12 days after surgery. All children were successfully treated without need for a repeated surgical intervention.

\section{Evaluation of Ganglion Cells in Myenteric Plexus}

Despite the visualisation of the cytoplasm of the ganglion cells in MAP-2 immunostaining which facilitated the process counting, we did not find statistically significant difference between immunostained and $\mathrm{H} \& \mathrm{E}$ sections (Fig. 1).

The ganglion cells count in the NZ and the TZ according to staining method are presented in $\mathrm{Ta}$ ble 1 . We observed a negative correlation between 


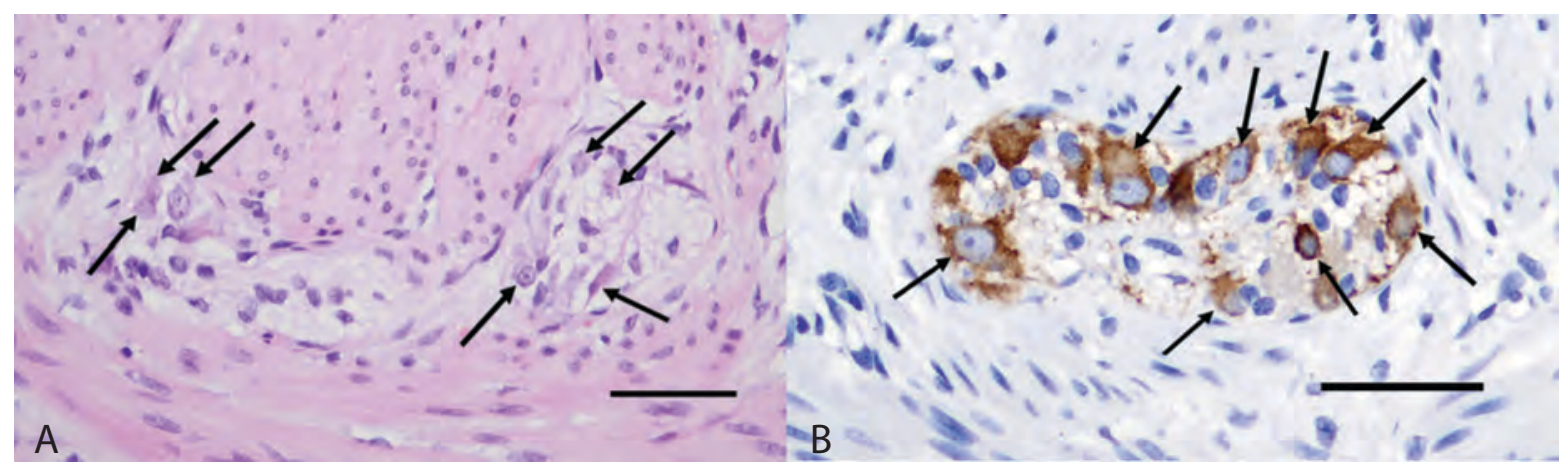

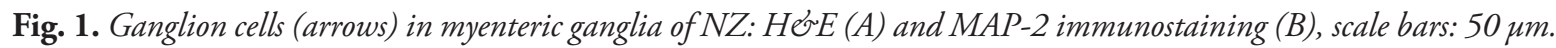

the count of ganglion cells in the NZ and children's age $(\rho=-0.388, P=0.026)$. The average count of ganglion cells per ganglia in the NZ and $\mathrm{TZ}$ was $3.5 \pm 1.29$ and $1.9 \pm 0.82$, respectively $(\mathrm{P}<0.001)$. Numerous submucosal nerves in the TZ could also be observed. The average diameter of submucosal nerves in NZ and TZ was $26 \pm 15.1$ and $46 \pm 22.8$, respectively $(\mathrm{P}<0.001)$.

Table 1. Number of Ganglion Cells in the Myenteric Plexus in NZ and TZ Regard to Staining Method

\begin{tabular}{llll}
\hline \multirow{2}{*}{ HD zone } & \multicolumn{2}{l}{$\begin{array}{l}\text { Number of ganglion cells regard to } \\
\text { staining method }\end{array}$} & P-value \\
\cline { 2 - 3 } & $\mathrm{H} \& \mathrm{E}\left(\overline{\mathrm{X}}_{ \pm} \mathrm{SD}\right)$ & MAP-2 $\left(\overline{\boldsymbol{X}}_{ \pm S \mathrm{SD}}\right)$ & \\
\hline $\mathrm{NZ}$ & $30 \pm 14.0$ & $30 \pm 14.5$ & 0.694 \\
\hline $\mathrm{TZ}$ & $8 \pm 6.8$ & $9 \pm 5.9$ & 0.460 \\
\hline P-value & $<0.001$ & $<0.001$ & \\
\hline
\end{tabular}

$\mathrm{HD}=$ Hirschsprung disease; $\mathrm{NZ}=$ Normoganglionic zone;

$\mathrm{TZ}=$ Transitional zone; 'Wilcoxon signed-rank test.

\section{Analysis of the ICC}

We observed a lower count of the ICC in the TZ compared to the NZ of the study group (Table 2). We found statistically significant negative correlation between the c-Kit positive cells in the myenteric region of the NZ and children's age ( $\rho=-0.383$, $\mathrm{P}=0.028$ ), but there was no significant correlation between the count of myenteric ganglion cells and ICC-MP $(\rho=0.129 ; \mathrm{P}=0.473)$.
Table 2. Number of Interstitial Cells of Cajal in Different Layers of Normoganglionic and Transitional Zone $(\mathrm{N}=33)$

\begin{tabular}{llll}
\hline $\begin{array}{l}\text { Layer of the intestinal } \\
\text { wall }\end{array}$ & $\begin{array}{l}\text { NZ } \\
\text { (median; } \\
\text { range) }\end{array}$ & $\begin{array}{l}\text { TZ } \\
\text { (median; } \\
\text { range) }\end{array}$ & P-value* \\
\hline Submucosal layer & $5(1-13)$ & $3(0-7)$ & $<0.001$ \\
\hline Circular muscular layer & $38(9-91)$ & $15(2-40)$ & $<0.001$ \\
\hline $\begin{array}{l}\text { Zone of myenteric } \\
\text { plexus }\end{array}$ & $32(12-64)$ & $16(5-34)$ & $<0.001$ \\
\hline $\begin{array}{l}\text { Longitudinal muscular } \\
\text { layer }\end{array}$ & $26(7-82)$ & $14(6-48)$ & $<0.001$ \\
\hline Total number of ICC & $108(52-214)$ & $53(29-113)$ & $<0.001$ \\
\hline
\end{tabular}

$\mathrm{NZ}=$ Normoganglionic zone of Hirschsprung disease; $\mathrm{TZ}=$ Transitional zone of Hirschsprung disease;"Wilcoxon signed-rank test.

\section{Analysis of Myenteric Ganglion Cells and ICC in the Control and Age-Matched NZ Group}

Due to significant correlation in count of the myenteric ganglion cells and ICC-MP related to age, we compared the results of morphometry of the control group with age-matched NZ. The median count of myenteric ganglion cells in the control group and age-matched NZ was 30 (range $14-47$ ) and $31(10-68)$, respectively $(\mathrm{P}=0.940)$.

The highest density of the ICC in the control and age-matched NZ was noted in the zone of the myenteric plexus (Fig. 2).

We observed a significantly lower ICC count in muscular layers of the age-matched NZ compared to the control group, while there were no significant differences in the submuscosal layer and zone of myenteric plexus (Table 3). 


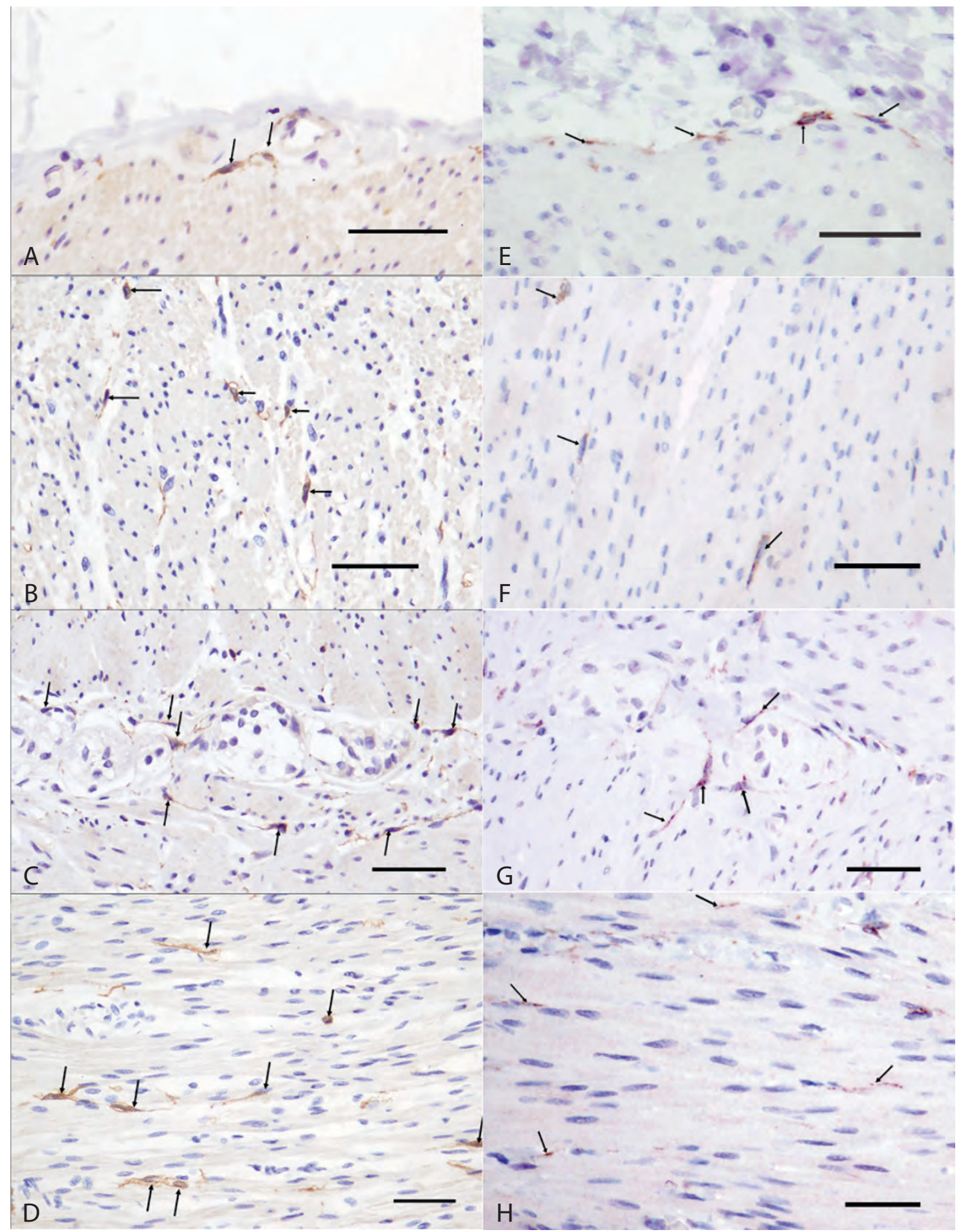

Fig. 2. Appearance and distribution of interstitial cells of Cajal (arrows) in a different layers of control sections: deep submucosal plexus (A), circular muscular layer (B), zone of myenteric plexus $(C)$, and longitudinal muscular layer $(D)$ and in $N Z$ of HD patients: deep submucosal plexus (E), circular muscular layer $(F)$, zone of myenteric plexus $(G)$, and longitudinal muscular layer $(H)$ (c-Kit immunostaining, scale bars: $50 \mu \mathrm{m}$ ). 
Table 3. Distribution of Interstitial Cells of Cajal in Control Group ( $N=10)$ and Normoganglionic Zone of Age-Matched Cases of Hirschsprung Disease $(\mathrm{N}=10)$

\begin{tabular}{llll}
\hline Layer of the bowel wall & $\begin{array}{l}\text { CG ICC number } \\
\text { (median; range) }\end{array}$ & $\begin{array}{l}\text { NZ ICC number } \\
\text { (median; range) }\end{array}$ & $\begin{array}{l}\text { P-value } \\
\text { (CG vs. NZ) }\end{array}$ \\
\hline Submucosal layer & $8(4-11)$ & $5.5(2-13)$ & 0.149 \\
\hline Circular muscular layer & $79(52-133)$ & $28.5(9-76)$ & $<0.001$ \\
\hline Zone of myenteric plexus & $40(22-63)$ & $36(28-59)$ & 0.545 \\
\hline Longitudinal muscular layer & $88.5(68-138)$ & $22.5(9-81)$ & $<0.001$ \\
\hline Total number of ICC & $230(167-303)$ & $96.5(63-166)$ & $<0.001$ \\
\hline
\end{tabular}

CG=Control group; NZ=Normoganglionic zone of Hirschsprung disease; ICC=Interstitial cells of Cajal; "Wilcoxon signed-rank test.

All children with postsurgical problems comprised the age-matched HD group and all of them underwent the same surgical procedure - TEPT. We observed a critically lower total ICC count (lower than 85.5) in the age-matched NZ only in children with postsurgical problems. The main clinical and morphological data of the NZ age-matched HD cases are present in Table 4.

\section{Table 4. Clinical and Morphological Data of the Age-Matched Children with HD}

\begin{tabular}{|c|c|c|c|c|c|c|c|}
\hline $\begin{array}{l}\text { Child } \\
\text { with } \\
\text { HD }\end{array}$ & $\begin{array}{l}\text { Length } \\
(\mathrm{cm})\end{array}$ & $\mathrm{Age}^{\dagger}$ & $\begin{array}{l}\text { Preoperative } \\
\text { sympoms }\end{array}$ & Irigography & $\begin{array}{l}\text { Total ICC } \\
\text { number of NZ }\end{array}$ & $\begin{array}{l}\text { Family/ personal } \\
\text { history }\end{array}$ & $\begin{array}{l}\text { Postoperative } \\
\text { problems }\end{array}$ \\
\hline 1 & 19 & 1.3 & $\begin{array}{l}\text { DEMS, } \\
\text { constipation }\end{array}$ & $\begin{array}{l}\text { Suspicious } \\
\text { to HD }\end{array}$ & 166 & - & No \\
\hline 2 & 21 & 1 & $\begin{array}{l}\text { Constipation, } \\
\text { abdominal } \\
\text { distension }\end{array}$ & $\begin{array}{l}\text { Suspicious } \\
\text { to small } \\
\text { left colon }\end{array}$ & $80^{\ddagger}$ & $\begin{array}{l}\text { Older siblings: } \\
\text { constipation }\end{array}$ & Constipation \\
\hline 3 & 14 & 1.5 & FPM, constipation & HD & 102 & - & No \\
\hline 4 & 47 & 1 & $\begin{array}{l}\text { Constipation, } \\
\text { vomiting }\end{array}$ & $\mathrm{HD}$ & $85^{\ddagger}$ & - & Constipation \\
\hline 5 & 25 & 1.5 & FPM, constipation & HD & 154 & - & No \\
\hline 6 & 15 & 3.5 & FPM, constipation & $\mathrm{HD}$ & 137 & $\begin{array}{l}\text { Bilateral testicular } \\
\text { retention }\end{array}$ & No \\
\hline 7 & 23 & 2 & $\begin{array}{l}\text { DEMS, } \\
\text { constipation }\end{array}$ & HD & $76^{\ddagger}$ & - & $\begin{array}{l}\text { Enterocolitis (12 } \\
\text { days post surgery) }\end{array}$ \\
\hline 8 & 27 & 2 & $\begin{array}{l}\text { DEMS, } \\
\text { constipation }\end{array}$ & $\begin{array}{l}\text { Suspicious } \\
\text { to HD }\end{array}$ & 96 & Older brother: HD & No \\
\hline 9 & 15 & 1 & $\begin{array}{l}\text { DEMS, } \\
\text { constipation }\end{array}$ & $\mathrm{HD}$ & $63^{\ddagger}$ & - & Constipation \\
\hline 10 & 19 & 1.2 & FPM, constipation & $\begin{array}{l}\text { Suspicious } \\
\text { to HD }\end{array}$ & 97 & - & No \\
\hline
\end{tabular}

*Length of the resected bowel; HD=Hirschsprung disease; DEMS=Delayed evacuation of meconial stool; FPM=Failled to pass meconium; ICC=Interstitial cells of Cajal; †Months; $¥$ ICC number $<50 \%$ of minimal ICC number in control group.

\section{Discussion}

The first part of this study implied evaluation of the myenteric nervous plexus and the submucosal nerve trunks in samples from the NZ and TZ for their validation. There are different approaches for the enteric nervous system evaluation. Orientation and size of the tissue samples, as well as the method of staining impact on total count of ganglion cells (16). For these reasons, in the present study all sec- 
tions (in NZ, TZ and control group) had the same orientation. Although numerous antibodies were applied to visualize ganglion cells (18), we used MAP-2 because of its sensitivity for the ganglion cells, without labelling other neural elements $(19,20)$.

ICC originate from the mesoderm, unlike the enteric nervous system cells. They are located along the entire gastrointestinal tract, from the upper oesophageal sphincter to the internal sphincter of the anus (7). However, they differ in distribution relative to their location within the gastrointestinal tract $(7,21)$. In the colon, they appear first in its proximal segment, at 9-10 gestational weeks (14). Count of the ICC cells and their volume within the human stomach and colon decrease with age, similarly to count of ganglia and ganglion cells $(22,23)$. This phenomenon was confirmed in our study - there was a statistically significant negative correlation between age and the count of ICC-MP in the NZ.

Due to different approaches to the ICC analysis, comparison of the total ICC count with the other studies is often difficult (16). In some studies frozen sections of bowel tissue were evaluated $(10,11$, $12,24)$. Other authors perform the whole-mounts preparation $(4,25)$. Another way of evaluations is to use paraffin tissue blocks $(26,9)$. Also, semiquantitative ICC analysis was performed in some studies $(4,9,10,25)$, while quantitative evaluation in several studies was carried out applying different methods $(11,12,24,26)$. However, despite limitations on standard paraffin sections (which reflects only partially the complex morphology of the ICC network), it is clear that the total ICC count in the TZ in our study was significantly lower than in the NZ, within all layers of the bowel. Similar findings were reported by Rolle et al. (4), Yamataka et al. (10) and Anatol et al. (27), but their results cannot be compared with our because of the different methodologies that have been applied. On the other hand, some authors did not note significant differences in ICC count relative to different HD segments $(8,9)$. We would to highlight that total number of cases with samples from NZ in many quantitative and semiquantitative ICC studies was lower than in our study, range $6-27(4,8,9,10$,
11, 12). It is well known that small samples could significantly affect the research results.

Anatol et al. reported significantly lower ICC count in the NZ compared the control group, similar to our study (26). Contrary to this research, some authors did not find differences in the ICC count in NZ $(4,11,12)$. All of these researches had small number of cases $(7-15)$ and applied different methodology, which makes them incomparable with our results. Chen et al. describes that differences in ICC count occur even within NZ - ICC count is higher at proximal resection margin than in distal level of NZ (27). Chronic constipation in HD could lead to damage of ultrastructural ICC morphology which results as loss of c-Kit expression. Bettolli et al. described loss of c-Kit expression and ultrastructural changes in acute appendicitis and increase of c-Kit immunoexpression after recovery (interval appendicitis) (28). Complete recovery of the intestinal motility in children who had postoperative problems in our study could be a confirmation of a hypothesis that altered ICC in HD is more likely a secondary phenomenon (7). However, significantly lower ICC count in the NZ is related to poor clinical outcomes and could be a predictor of poor clinical outcome $(11,12,26)$.

Lower total ICC count in age-matched NZ compared with control in the present study was related to lower ICC count in the muscular coat, while differences in the ICC-SP and ICC-MP were not statistically significant. The depletion of the ICC in the muscular layers of the gut may contribute to the inability of relaxation of the smooth muscle (6) and may contribute to postoperative constipation.

The vast majority of authors used c-Kit antibody for ICC identification. Expression of c-Kit is also characteristic of mast cells, hematopoietic stem cells, melanocytes, mesenchymal stem cells (29). ICC are heterogeneous population of cells, which include at least three different types within the muscular coat of the intestines, with different functions. Beside pacemaker motility role, there are role in conduction of electrical impulses from the pacemaker ICC cells and role in mediation 
of inhibitory and excitatory motor transmission (30). However, recent studies suggest that another marker of ICC - anoctamin 1 is more specific and sensitive for ICC, especially as reflection of their function in HD (31). New dilemmas about ICC count are also related to presence of ICC-like cells or telocytes, which are also c-Kit positive cells. Also there are still doubts - are they new cell type or subpopulation of ICC (29).

Because of variability in ICC count, the Gastro 2009 International Working Group recommended that a reduction of the ICC count more than 50\% should only be reported (16). Our finding in the present study support this because only children with postoperative problems had critically lower ICC count in the NZ. Further investigations of the ICC, with larger HD series and control groups are necessary to better understand clinical implications of the altered ICC network.

\section{Conclusion}

Our study showed impairment of the ICC network of the TZ in all children with HD. ICC network was significantly altered even in the NZ. The ICC network is even significantly altered in the NZ. A critically lower ICC count (less than 50\% of minimal ICC count in the control group) in sections from the NZ could be related to postsurgical constipation when other causes, such as presence of the $\mathrm{TZ}$, are excluded. Immunostaining of tissue sections from paraffin blocks is relatively simple for usage in routine daily practice for ICC analysis, but ICC evaluation in HD requires adequate referent values, which require analysis of a sufficient control tissue samples.

Conflict of Interest: The authors declare that they have no conflict of interest.

Authors' Contributions: Conception and design: RJ, SSA, ML, DV, JJ, and MSG; Acquisition, analysis and interpretation of data: RJ, SSA, ML, DV, JJ, and MSG; Drafting the article: RJ; Revising it critically for important intellectual content: SSA, ML, DV, JJ, and MSG; Approved final version of the manuscript: RJ, SSA, ML, DV, JJ, and MSG.

\section{References}

1. Butler Tjaden NE, Trainor PA. The developmental etiology and pathogenesis of Hirschsprung disease. Transl Res. 2013;162(1):1-15.

2. Kapur RP, Kennedy AJ. Transitional zone pull through: surgical pathology considerations. Sem Pediatr Surg. 2012;21(4):291-301.

3. Boman F, Steir R, Prisco R, Bonnevalle M, Besson R. Advantages of intraoperative semiquantitative evaluation of myenteric plexuses in patients with Hirschsprung disease. J Pediatr Surg. 2007;42(6):1089-94.

4. Rolle U, Piotrowska AP, Nemeth L, Puri P. Altered Distribution of Interstitial Cells of Cajal in Hirschsprung Disease. Arch Pathol Lab Med. 2002;126(8):928-33.

5. Kessmann J. Hirschsprung's Disease: Diagnosis and Management. Am Fam Physician. 2006;74(8):1319-22.

6. Breuer C. The Role of Interstitial Cells of Cajal (ICC) in Gastrointestinal Motility Disorders - What the Gastroenterologist Has to Know, Constipation - Causes, Diagnosis and Treatment, Dr. Anthony Catto-Smith (Ed.), ISBN: 978-953-51-0237-3, InTech; 2012.

7. Gfroerer S, Rolle U. Interstitial cells of Cajal in the normal human gut and in Hirschsprung disease. Pediatr Surg Int. 2013;29(9):889-97.

8. Horisawa M, Watanabe Y, Torihashi S. Distribution of ckit immunopositive cells in normal human colon and in Hirschsprung's disease. J Pediatr Surg. 1998;33(8):1209-14.

9. Newman CJ, Laurini RN, Lesbros Y, Reinberg O, Meyrat BJ. Interstitial cells of Cajal are normally distributed in both ganglionated and aganglionic bowel in Hirschsprung's disease. Pediatr Surg Int. 2003;19(9-10):662-8. doi:10.1007/ s00383-003-1026-1

10. Yamataka A, Kato Y, Tibboel D, Murata Y, Sueyoshi N, Fujimoto T, et al. A lack of interstitial pacemaker (c-kit) in aganglionic bowel of patients with Hirschsprung's disease. J Pediatr Surg. 1995;30(3):441-4.

11. Bettolli M, De Carli C, Jolin-Dahel K, Bailey K, Khan HF, Sweeney B, et al. Colonic dysmotility in postsurgical patients with Hirschsprung's disease. Potential significance of abnormalities in the interstitial cells of Cajal and the enteric nervous system. J Pediatr Surg. 2008;43(8):1433-8.

12. Taguchi T, Suita S, Masumoto K, Nagasaki A. An abnormal distribution of c-kit positive cells in the normoganglionic segment can predict a poor clinical outcome in patients with Hirschsprung's disease. Eur J Pediatr Surg. 2005;15(3):153-8.

13. Ippolito C, Segnani C, De Giorgio R, Blandizzi C, Mattii L, Castagna M, et al. Quantitative evaluation of my- 
enteric ganglion cells in normal human left colon: implications for histopathological analysis. Cell Tissue Res. 2009;336(2):191-201.

14. Abramovic M, Radenkovic G, Velickov A. Appearance of interstitial cells of Cajal in the human midgut. Cell Tissue Res. 2014;356(1):9-14.

15. Yu CS, Kim HC, Hong HK, Chung DH, Kim HJ, Kang $\mathrm{GH}$, et al. Evaluation of myenteric ganglion cells and interstitial cells of Cajal in patients with chronic idiopathic constipation. Int J Colorectal Dis. 2002;17(4):253-8.

16. Knowles CH, De Giorgio R, Kapur RP, Bruder E, Farrugia $\mathrm{G}$, Geboes $\mathrm{K}$, et al. Gastrointestinal neuromuscular pathology: guidelines for histological techniques and reporting on behalf of the Gastro 2009 International Working Group. Acta Neuropathol. 2009;118(2):271-301.

17. Kanda Y. Investigation of the freely available easy-to-use software 'EZR' for medical statistics. Bone Marrow Transplant. 2013;48(3):452-8.

18. Bachmann L, Besendörfer M, Carbon R, Lux P, Agaimy A, Hartmann A, et al. Immunohistochemical panel diagnostics of Hirschsprung's disease with Map2, calretinin, Glut1 and S100. Histopathology. 2015;66(6):824-35.

19. Yang WI, Oh JT. Calretinin and microtubule-associated protein-2 (MAP-2) immunohistochemistry in the diagnosis of Hirschsprung's disease. J Pediatr Surg. 2013;48(10):2112-7.

20. Burtelow MA, Longacre TA. Utility of microtubule associated protein-2 (MAP-2) immunohistochemistry for identification of ganglion cells in paraffin-embedded rectal suction biopsies. Am J Surg Pathol. 2009;33(7):1025-30.

21. Torihashi S, Horisawa M, Watanabe Y. C-kit immunoreactive interstitial cells in the human gastrointestinal tract. J Auto Nerv Syst. 1999;75(1):38-50.

22. Knowles CH, Veress B, Kapur RP, Wedel T, Farrugia G, Vanderwinden JM, et al. Quantitation of cellular components of the enteric nervous system in the normal human gastrointestinal tract - report on behalf of the Gastro 2009
International Working group. Neurogastroenterol Motil. 2011;23(2):115-24.

23. Gomez-Pinilla PJ, Gibbons SJ, Sarr MG, Kendrick ML, Shen KR, Cima RR, et al. Changes in interstitial cells of Cajal with age in the human stomach and colon. Neurogastroenterol Motil. 2011;23(1):36-44.

24. Wang H, Zhang Y, Liu W, Wu R, Chen X, Gu L et al. Interstitial cells of Cajal reduce in number in recto-sigmoid Hirschsprung's disease and total colonic aganglionosis. Neurosci Lett. 2009;451(3):208-11.

25. Solari V, Piotrowska AP, Puri P. Histopathological differences between recto-sigmoid Hirschsprung's disease and total colonic aganglionosis. Pediatr Surg Int. 2003;19(5):349-54.

26. Anatol T, Mohammed W, Rao C. Interstitial cells of Cajal and intestinal function in Trinidadian children. West Indian Med J. 2008;57(4): 393-7.

27. Chen X, Zhang H, Li N, Feng J. Pathological changes of interstitial cells of Cajal and ganglion cells in the segment of resected bowel in Hirschsprung's disease. Pediatr Surg Int. 2016;32(11):1019-24.

28. Bettolli M, De Carli C, Cornejo-Palmab D, Jolin-Dahel $\mathrm{K}$, Wangd X, Huizingad J et al. Interstitial cell of Cajal loss correlates with the degree of inflammation in the human appendix and reverses after inflammation. J Pediatr Surg. 2012;47(10):1891-9.

29. Varga I, Kyselovič J, Danišovič L, Galfiova P, Kachlik D, Polak Š, et al. Recently discovered interstitial cells termed telocytes: distinguishing cell-biological and histological facts from fictions. Biologia. 2019;74:195-203.

30. Mostafa RM, Moustafa YM, Hamdy H. Interstitial cells of Cajal, the maestro in health and disease. World J Gastroenterol. 2010;16:3239-48.

31. Coyle D, Kelly DA, O'Donnell AM, Gillick J, Puri P. Use of anoctamin 1 (ANO1) to evaluate interstitial cells of Cajal in Hirschsprung's disease. Pediatr Surg Int. 2016;32:125-33. 